\title{
Krzysztof Kania, Maria Smolarek
}

Uniwersytet Ekonomiczny w Katowicach

e-mails:kkania@ue.katowice.pl; maria.smolarek@ue.katowice.pl

\section{ANALIZA ROZWOJU GAMIFIKACJI BIZNESOWEJ NA PRZYKLADZIE PRZEDSIĘWZIEĆC REALIZOWANYCH W POLSCE}

Streszczenie: Gamifikacja - jak każda nowa technologia - przechodzi kolejne fazy rozwoju. Na znanej krzywej cyklu życia Gartnera w roku 2013 znalazła się na samym szczycie: w fazie rozdmuchanych oczekiwań, a w roku 2014 weszła w fazę określaną jako rozwiewanie iluzji, z perspektywą wejścia do powszechnego użytkowania w okresie 5-10 lat. Celem artykułu jest dokonanie, na podstawie krajowej literatury, dostępnych w sieci informacji oraz informacji pozyskanych metodami bezpośrednimi, analizy rozwoju przedsięwzięć gamifikacji biznesowej popartej przykładami działań podejmowanych w Polsce oraz próba odpowiedzi na pytanie o przyszłość gamifikacji.

Słowa kluczowe: gamifikacja, nowe technologie, projekty gamifikacji w Polsce.

Summary: Gamification - like almost every new technology - goes through a few stages of development. On the well-known Gartner's Hype Cycle for new technologies in 2013, it was on the peak of inflated expectations, and in 2014 it entered the phase of trough of disillusioment, with the prospect of entering to mainstream adoption in 5-10 years. The aim of the article is to analyse - on the basis of literature, available information - the development of undertakings of business gamification projects supported by the examples of activities undertaken in Poland and an attempt to answer the question about the future of gamification.

Keywords: gamification, new technologies, gamification projects in Poland.

\section{Wstęp}

Gamifikacja jest nadal względnie nową ideą, która od kilku lat jest przedmiotem intensywnych badań, a która - zdaniem autorów - znalazła się na rozdrożu między wejściem na trwałe do arsenału informatycznych narzędzi wspomagających zarządzanie a zapomnieniem i odrzuceniem. W analizie autorzy skupili się na działaniach 
gamifikacyjnych podejmowanych w Polsce, również ze względu na brak takiego przeglądu w literaturze przedmiotu.

Artykuł zorganizowano następująco. Tekst rozpoczyna krótka charakterystyka zjawiska gamifikacji. W punkcie drugim przedstawiono kolejne stadia rozwoju technologii. Na tym tle w kolejnym punkcie dokonano przeglądu rozwiązań gamifikacyjnych w Polsce. Tekst zamyka podsumowanie, w którym zawarto wnioski i prognozę przyszłego rozwoju gamifikacji.

\section{Gamifikacja jako zjawisko społeczne}

Powszechne zaangażowanie ludzi w gry (granie) zostało dostrzeżone już w latach czterdziestych XX w., kiedy to J. Huizinga zwrócił uwagę na to, że znaczenie gry dla rozwoju społecznego jest znacznie większe, niż można przypuszczać, mimo iż potrzeba grania nie odwołuje się ani do instynktu, ani do rozsądku. Grę można uznać z założenia za niematerialną całościową jakość w naturze samej rzeczy [Huizinga 1949, s. 1]. Zjawisko to bardzo nasiliło się wraz z rozwojem technologicznym i od kilkunastu lat zaczęło być postrzegane jako ważny komponent życia społecznego, gospodarczego, kulturalnego i artystycznego [VerBruggen 2012].

Zwiększenie liczby osób, których zachowania są kształtowane przez gry spowodowało, że skalę i wagę zachodzących zmian zauważyli również specjaliści biznesowi. Podjęto liczne próby wykorzystania reguł gry do osiągania różnych celów organizacyjnych. Logika, atmosfera i techniczne elementy gry zostały zastosowane niemal we wszystkich dziedzinach życia i biznesu, poczynając od promocji zielonej energii (EcoIsland), przez budowanie lojalności dla kanałów telewizyjnych (GetGlue), podnoszenie jakości zdrowia (Fitocracy), na inicjowaniu zmian aspiracji życiowych (Mindbloom) [Hamari 2013] i zarządzaniu ryzykiem przedsięwzięć skończywszy [Bajdor, Dragolea 2011]. Liczne przykłady zastosowań można znaleźć między innymi w stale aktualizowanych serwisach [Chou 2015; Internet 5]. Objęto je wspólną nazwą „,gamifikacja” (w literaturze polskiej używane są również określenia „grywalizacja” i ,gryfikacja”).

Studia literatury przedmiotu pozwalają wyróżnić co najmniej cztery określenia gamifikacji. Zgodnie z pierwszym, najszerszym, wiązanym z nazwiskiem Deterdinga, uznaje się, że gamifikacja to wykorzystanie elementów gry w kontekście „niegry" [Hamari 2013]. Drugie z określeń akcentuje proces dostarczania ofert doznawania przeżyć (doświadczeń) dostępnych podczas gry, co ma wspierać ogólny proces tworzenia wartości dla klienta [Huotari, Hamari 2012]. Trzecie z możliwych określeń zwraca uwagę na zamiar i łączy gamifikację z wdrażaniem systemów perswazyjnych, mających na celu promowanie wybranego rodzaju aktywności [Zuckerman, Gal-Oz 2014]. Czwarte wskazuje zaś, że w centrum gamifikacji ,znajduje się system lub program, którym firma już dysponuje, a wokół niego dobudowuje się mechanizmy gamifikacji” [Paharia 2014, s. 89]; gamifikacja to wykorzystanie technik motywacji opartych na zbiorach danych [Paharia 2014, s. 31], ,jest również 
formą przetwarzania strumieni danych w czasie rzeczywistym" [Paharia 2014, s. 69]. W kontraście do definicji proponowanych w literaturze naukowej przytaczamy definicje przyjmowane przez P. Tkaczyka, aktywnego propagatora gamifikacji i organizatora projektów gamifikacji, który wskazuje, że na użytek podejmowanych przez siebie projektów przyjmuje następujące definicje [Tkaczyk 2012]:

- Grywalizacja to użycie mechanizmów znanych z gier (nie tylko komputerowych) do zmiany zachowań ludzi poza kontekstem gry.

- Grywalizacja to także „wstrzykiwanie frajdy” do czynności (takich jak praca, ranne wstawanie, oszczędzanie na emeryturę czy nauka), które normalnie frajdy nie sprawiają.

Szerszą dyskusję na temat definicji gamifikacji można znaleźć w [Huotari, Hamari 2016], niemniej widać wyraźnie, że nie można utożsamiać samej gry z gamifikacją i projektu gry z projektem gamifikacji.

Pojęciem zbliżonym do gamifikacji są gry poważne, zdefiniowane przez T. Connolly'ego i in. [2012] jako gry, których celem (czasami ukrytym) jest zmiana zachowań gracza lub jego nastawienia. $Z$ punktu widzenia biznesu najistotniejszy jest efekt uboczny gry, polegający na silniejszym przywiązaniu do marki, podniesieniu poziomu zaangażowania pracownika $\mathrm{w}$ pracę, a czasem poprawienia zadowolenia z pracy, co jednak powinno się przełożyć na lepsze efekty pracy.

Społeczny świat gier stał się jednym z wymiarów środowiska (otoczenia) firm. Poświęcanie grom coraz dłuższego czasu i rosnącą liczbę zaangażowanych graczy można wyjaśnić głównie postępem technologicznym, możliwościami współczesnych komputerów oraz rozpowszechnieniem się sieci. Zjawisko to oraz fakt, że pokolenie aktywnych graczy zaczyna współtworzyć organizację i jej otoczenie, niektórzy menedżerowie rozpatrują wyłącznie w kategoriach nowinki, którą być może warto wykorzystać. Inni postrzegają je w kategoriach adaptacji, a tylko nieliczni wskazują, że mamy do czynienia z konieczną zmianą o charakterze strategicznym (zob. szerzej [Strużyna, Kania 2016]).

Gamifikacja jest innowacyjną techniką biznesową, która może być wykorzystywana okazjonalnie do podniesienia atrakcyjności produktów lub w akcjach kreowania marki, ale może być również trwałą strategią organizacji, której celem jest zmiana środowiska pracy, postaw pracowników, a w szerszej skali również otoczenia biznesowego i społecznego organizacji.

\section{Obszary zastosowań gamifikacji}

Gamifikację można kategoryzować według różnych kryteriów. Ze względu na przedmiot (dziedzinę zastosowań) wyróżnia się następujące jej rodzaje [Internet 15; Internet 17]:

- Prosta gamifikacja produktowa, która polega na połączeniu produktu z grą w celu podniesienia atrakcyjności samego produktu.

- Gamifikacja marketingowa, w której gra jest elementem nowoczesnej dynamicznej kampanii marketingowej, której celem jest zbudowanie zaangażowanej 
społeczności skupionej wokół produktu lub marki. Gamifikacja produktowa lub marketingowa może mieć sprzężenie zwrotne lub nie. W gamifikacji bez sprzężenia zwrotnego szczegółowa informacja o działaniach graczy (poza zbudowaniem rankingu i wskazaniem nagrodzonych) nie jest przekazywana do organizatora gry ani analizowana, natomiast gamifikacja ze sprzężeniem zwrotnym polega na wykorzystaniu działań graczy do zmiany (udoskonalenia) oferowanego produktu lub usługi (Pizza Hero) lub pozyskania wiedzy o samych graczach.

- Gamifikacja miejsca (środowiska) pracy (workplace), której głównym celem jest wpływanie na pracowników i zespoły i motywowanie ich przez mechanizmy wynagradzania, komunikacji i współdziałania. Wbrew obawom niektórych menedżerów zgamifikowane miejsce pracy to nie miejsce pracy, w którym pracownicy grają $\mathrm{w}$ gry wideo lub stawiają pasjanse, zamiast pracować. Miejsce takie można opisać jako wzbogacone o elementy graficzne lub interakcyjne, znane z gier, które przekształcają procesy pracy w działania zbliżone do uczestnictwa w grze. Długofalowym celem tego typu gamifikacji jest poprawa zadowolenia pracownika z pracy, a przez to również podniesienie produktywności i satysfakcji z pracy [Oprescu, Jones, Katsikitis 2014; Mechelen 2016].

- Gamifikacja społeczna, która jest kierowana do lepiej lub gorzej określonych grup (dzieci, seniorzy), a która ma na celu wykształcenie określonych postaw społecznych (zachowania proekologiczne, kultura fizyczna, podniesienie poziomu bezpieczeństwa). Z gamifikacją społeczną spotykamy się również w organizacjach publicznych (szkoły, placówki kulturalne, placówki ochrony zdrowia, urzędy) przy promocji miast i regionów [Banuri 2016; Negrusa i in. 2015; Diamantaki i in. 2013; Orange 2017], wydarzeń historycznych [Internet 3], a nawet w wymiarze sprawiedliwości [Alexandrova, Rapanotti, Horrocks 2016].

- Gamifikacja personalna (lifestyle), która skierowana jest do indywidualnych osób i związana jest z programami prozdrowotnymi, treningowymi, ubezpieczeniowymi itp. (zob. np. [Heong Weng Mak 2016]).

Podział ten nie jest rozłączny, ponieważ np. gamifikacja personalna może być połączona z marketingową, gdy konkretna forma, kierując ofertę do swoich klientów, jednocześnie promuje swoją markę (np. program Nike+ [Kuo 2015]).

Z kolei ze względu na stopień skupienia (focus) na grupie docelowej można wyróżnić gamifikację społeczną (najszersza liczba uczestników), biznesową zewnętrzną (klienci i otoczenie firmy - B2C), biznesową wewnętrzną (B2E - ogół pracowników) i funkcjonalną/zadaniową (skierowaną do pracowników konkretnych działów lub uczestników konkretnych procesów).

$\mathrm{Na}$ tle tych wszystkich ustaleń, w opracowaniu autorzy uznali, że gamifikacja biznesowa może być traktowana jako proces włączania narzędzi i elementów gry oraz towarzyszących im mechanizmów społecznych oraz psychologicznych (m.in. ofertowania i perswazji) w system doskonalenia organizacji (środowisko tzw. niegry). 


\section{Stadia rozwoju technologii}

Gamifikacja na znanej krzywej cyklu życia nowych technologii Gartnera w roku 2013 znalazła się na samym szczycie - w fazie rozdmuchanych oczekiwań, a w roku 2014 weszła w fazę określaną jako rozwiewanie iluzji, z perspektywą wejścia do powszechnego użytkowania w okresie 5-10 lat. W roku 2014 eksperci IEEE przewidywali, że do roku 2020 co najmniej $85 \%$ wszystkich codziennych czynności, takich jak zakupy, uczenie się, leczenie, praca, będzie zawierało jakieś elementy gier [IEEE 2014]. Na te lata datują się również największe sukcesy takich firm, jak Badgevill czy Bunchball, które zaoferowały programy i platformy gamifikacji. Warto zauważyć, że sukces ten został odniesiony bez żadnych doświadczeń z przeszłości, a firmy, które podjęły się realizacji projektów, poddały się entuzjazmowi związanemu z nową technologią i liczyły na nadzwyczajne korzyści z tytułu wprowadzenia gamifikacji albo kierowały się naśladownictwem.

Jednak już w roku 2012, kiedy na fali entuzjazmu związanego z ideą gamifikacji rozpoczęło się wiele projektów, eksperci Instytutu Gartnera przewidywali, że do roku 2014 aż $80 \%$ z nich zakończy się bez osiągnięcia celów biznesowych z powodu słabego przygotowania projektu [Gartner 2012]. I rzeczywiście, w roku 2014 kilka dużych firm spektakularnie wycofało się z projektów gamifikacji, m.in. FourSquare, które wskazało, że efekt związany z wprowadzeniem do serwisu punktacji i odznak minął i program nie przynosi dalszych spodziewanych rezultatów. Okazało się, że znaczna część projektów gamifikacji kończy się porażką [Gamification Failures] i jest prawdopodobne, że lista projektów zaniechanych lub nieudanych jest znacznie dłuższa. Zrozumiano wtedy, że gamifikacja nie polega na dodaniu do punktów odznak i poziomów, a tym bardziej nie polega na organizowaniu kolejnych konkursów. Tak widziana, nie przynosi dobrych ani tym bardziej trwałych efektów. Pozostaje rozczarowanie i konstatacja, że gamifikacja nie działa. Część menedżerów błędnie widziała w gamifikacji tanie, szybkie i skuteczne remedium na niemalże wszystkie bolączki zarządzania (w szczególności związane z motywowaniem pracowników), co było podejściem niesłusznym. Dlatego obecnie trwają intensywne badania już wdrożonych projektów i poszukiwania wskazówek metodycznych skutecznego wdrażania projektów gamifikacji oraz krytycznych czynników sukcesu (zob. np. [Morschheuser i in. 2017]).

Autorzy postawili tezę, że gamifikacja stanęła na rozdrożu wejścia do fazy oświecenia (slope of enlightment) i na wyżyny dojrzałości (plateau of productivity), zwyczajnego użytkowania (swamp of continued use) lub zaniechania projektów i zapomnienia (trash heap of failure) (rys. 1); zob. [Algoso 2014].

Aby ją zweryfikować, proponujemy, na przykładzie przedsięwzięć gamifikacyjnych w Polsce, wprowadzony podział gamifikacji na obszary połączyć z informacjami dotyczącymi czasu i trwałości podejmowanych działań. Za pewną miarę trwałości działań gamifikacyjnych w organizacji przyjęto 4-stopniową skalę, pokrewną poziomom wyszczególnionym w [Strużyna, Kania 2016]. 


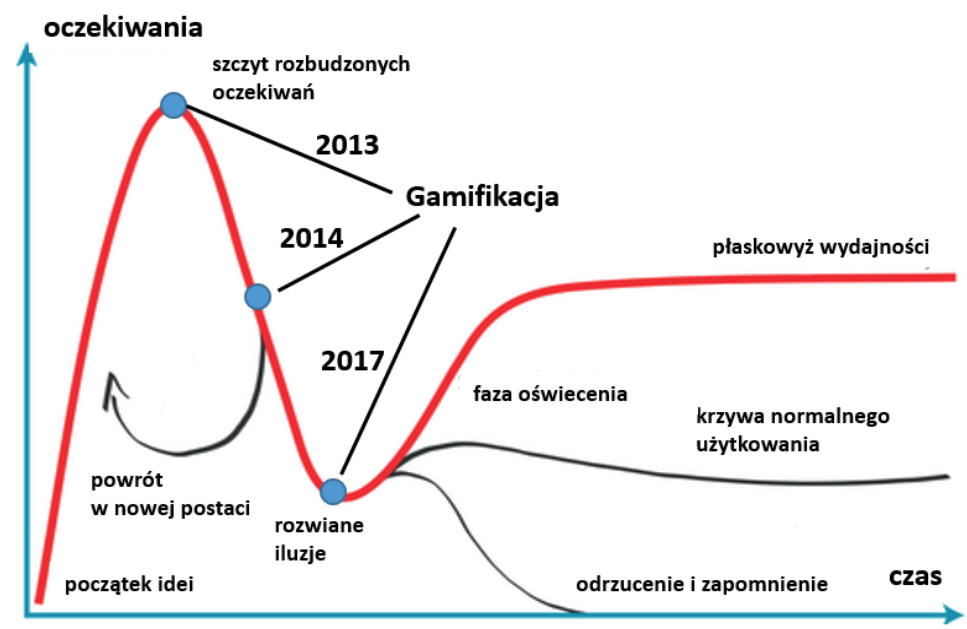

Rys. 1. Gamifikacja na krzywej rozwoju technologii Instytutu Gartnera

Źródło: opracowanie własne na podstawie [Internet 6; Internet 7; Algoso 2014].

Poziom 1 - to incydentalne zastosowanie, dodanie gry do produktu, wykorzystanie gry w procesie rekrutacji pracowników, szkoleniach i doskonaleniu pracowników. Krótkotrwałe i okazjonalne dopasowanie do trendów, mody, oczekiwań rynku itd. Motywacja podjęcia działań wynika głównie z naśladownictwa, próby dopasowania się do trendu lub mody. Celem gamifikacji jest próba doraźnego zwiększenia sprzedaży, zmotywowania pracowników do wykonania jakiegoś zadania, zwiększenie zainteresowania marką.

Poziom 2 - to powtarzalne wykorzystanie gamifikacji jako narzędzia wspierania zadań biznesowych lub rozwiązywania problemów występujących w organizacji. Projekty gamifikacji prowadzone są metodycznie z wyraźnie zaznaczonymi celami biznesowymi. Następuje wykorzystanie elementów gier w procesach organizacji, włączanie stałych mechanizmów związanych z grami do działania organizacji. Działanie jest motywowane pozytywnymi wynikami wcześniejszych projektów, obliczone na osiągnięcie dopasowania w obszarach funkcjonalnych. Cele gamifikacji w tej fazie to trwałe zwiększenie zaangażowania pracowników i klientów w działania korzystne dla organizacji, rozwiązanie jakiegoś problemu organizacji lub zdobycie wiedzy o organizacji lub jej otoczeniu.

Poziom 3 - to systematyczne wykorzystanie elementów gier w procesach organizacji, włączanie stałych mechanizmów związanych z grami do działania organizacji, której celem jest planowe, długotrwałe działania obliczone na osiągnięcie dopasowania między oczekiwaniami (szczególnie młodych) pracowników a wymaganiami biznesowymi w sferze kultury organizacji.

Poziom 4 - to stała gotowość do odpowiedzi na współpracę ze społeczeństwem gry i pracownikami, klientami, kooperantami - graczami. Organizacja z zewnątrz jest postrzegana jako uczestnik społeczeństwa gry. 


\section{Przykłady wykorzystania działań gamifikacyjnych w Polsce}

Analizie poddano przykłady dostępne na stronach firm oferujących pomoc w przeprowadzeniu projektów, które sami zainteresowani określili jako gamifikacyjne, m.in.: Gamfi - www.gamfi.pl, Sointeractive - www. Sointeractive.pl, gerere.com.

Przykładami podjęcia działań gamifikacyjnych na poziomie pierwszym są S4You [Internet 12] oraz Sony Computer Entertainment. S4You to aplikacja, która została wykorzystana w ramach kampanii promocyjnej Samsung GALAXY S4. Celem aplikacji była edukacja fanów w zakresie funkcjonalności smartfona oraz zaangażowanie ich do jego promocji wśród swoich znajomych. Sony Computer Entertainment to $\mathrm{z}$ kolei aplikacja stworzona do kampanii Playstation $4 \mathrm{w}$ celu promocji nowej konsoli, gier oraz usługi PS+. Warto zauważyć, że jakikolwiek tradycyjny komunikat reklamowy ze względu na czas jego emisji nie pozwala przedstawić i nauczyć korzystania ze wszystkich funkcjonalności reklamowanego produktu. Wykorzystanie w tym celu mechanizmów gier pozwala w atrakcyjny sposób zachęcić do poznania i propagowania oferowanych przez dany produkt funkcjonalności.

Dobrymi przykładami wykorzystania gamifikacji na poziomie drugim są aplikacje: Odkrywaj i Wygrywaj, Brygada 7 Zbóż, HBO Play, Akademia Asów, Dobry Agent.

Aplikacja Odkrywaj i Wygrywaj [Internet 10] pozwala użytkownikom poznać świat usług w Play, koncentrując się na zapoznawaniu się z usługami dodanymi, jak np. Audioteka, WiMP czy Bezpieczna Rodzina. Po samodzielnym wykonaniu zadań użytkownik może polecać usługi znajomym, stając się w ten sposób ambasadorem marki.

Aplikacja Brygada 7 Zbóż [Internet 11] to miejsce, w którym konsumenci zapoznają się z cechami i zaletami produktów marki Bakoma. Narracja aplikacji bazuje na fabularnych postaciach Brygady.

HBO Play [Internet 13] to aplikacja wykorzystująca gamifikację na Facebooka przygotowana jako długoterminowa platforma do promocji seriali i programów HBO Polska i HBO GO. Aplikacja może zmieniać swój wygląd w zależności od promowanego serialu. Użytkownicy angażują się w świat marki, wykonując zadania samodzielnie lub wciągając w to swoich znajomych.

Program gamifikacyjny Red Bulla, którego fabuła jest związana z pokazami akrobacji lotniczych w Trójmieście, adresowany był do przedstawicieli handlowych. Jednak, oprócz fabuły i otoczki marketingowej, istotnym elementem są gromadzone dane. Firma, chcąc zwiększyć zaangażowanie przedstawicieli handlowych w pracę przez zabawę i osiągnięcie jak najlepszych wyników, przygotowała dla nich program, któremu nadano nazwę Akademia Asów Świat Red Bulla [Internet 8].

Z kolei firma ubezpieczeniowa Gothaer zdecydowała się na zastosowanie gamifikacji w programie motywacyjnym dla agentów w sieci sprzedaży o nazwie Dobry Agent [Internet 1]. Dzięki aktywności swoich pracowników na platformie Gothaer dowiaduje się, jakie informacje w sposób szczególny są dla nich cenne, co sprzyja osiąganiu lepszych wyników. Platforma buduje społeczność pracowniczą i sprzyja identyfikacji z pracodawcą oraz ułatwia komunikację na linii Gothaer-agenci. 
Przykładami zastosowań działań gamifikacyjnych na poziomie trzecim są aplikacje: HAYS, Inspiratorium Menedżer 2.0, Autostrada Rozwoju, Drabina Rozwoju oraz GetBadges.

Firma HAYS Recruiting Experts Worldwide wykorzystuje działania gamifikacyjne w procesach rekrutacji [Internet 14]. Na początku projektu została precyzyjnie określona grupa docelowa; scharakteryzowano ją jako osoby w wieku 20-30 lat, władające minimum dwoma językami obcymi. Celem wdrożenia programu było przyciągnięcie jak największej grupy takich osób do aplikacji, aby przez procesy gamifikacji wykorzystać potencjał posiadanych przez nich siatki kontaktów w celu rekomendacji kandydatów do pracy.

Inspiratorium Menedżer 2.0 [Internet 9] to platforma wykorzystywana w Grupie PZU, pozwalająca nie tylko na wspieranie szkoleń oraz utrwalanie wiedzy, ale i na wykorzystanie wiedzy w codziennej pracy przez angażowanie i ciągłe motywowanie pracowników do jej pogłębiania i samodzielnego poszukiwania. Nadrzędnym celem jej zastosowania było zachęcenie pracowników do samokształcenia i stworzenie optymalnych warunków do ich rozwoju. Zadaniem Inspiratorium Menedżer 2.0 jest przede wszystkim sprawienie, by pracownicy myśleli perspektywicznie o samokształceniu w kontekście własnej kariery zawodowej.

Zwiastunem przemyślanego podejścia do wewnętrznej gamifikacji biznesowej jest sukces polskiej firmy GetBadges oferującej grę typu RPG, która może zostać zintegrowana $\mathrm{z}$ ok. 20 różnymi środowiskami wspierającymi pracę zespołów wytwarzających oprogramowanie (m.in. GitHub, Trello). W grze uczestniczą wszyscy zaangażowani w produkcję oprogramowania (programiści, testerzy). Wykonując powierzone zadania biznesowe, jednocześnie walczą z potworami, zdobywają odznaki i punkty oraz inne atrybuty znane z gier tego typu. Obecnie firma szczyci się ponad 1200 klientami na całym świecie, a jej produkt jest bardzo wysoko oceniany przez klientów i recenzentów [Internet 16]. Sukcesu produktu można upatrywać w dobrze określonej grupie docelowej i charakterze pracy programistów. Ich działania niemal w całości prowadzone są z użyciem komputera i odbywają się w cyberprzestrzeni, podobnie jak prowadzona gra, więc połączenie obu światów jest względnie łatwe. Pracownicy mogą rozgrywać grę, po prostu pracując, albo inaczej - można było łatwo połączyć świat i mechanikę gry z wykonywanymi przez nich zadaniami.

Program Autostrada Rozwoju (Internet 4) zrealizowany w firmie INTER CARS $\mathrm{w}$ formie fabularnej gry kompetencyjnej i zgrywalizowany program talentów i sukcesorów Drabina Rozwoju [Internet 4], wdrożony w Leroy Merlin Polska, to przykład wprowadzenia gamifikacji w obszar zarządzania rozwojem pracowników, motywowania ich do permanentnego nabywania nowej wiedzy i kompetencji.

Przykładem wykorzystania gamifikacji na poziomie czwartym jest program menedżerski Global Management Challenge (GMC) [Internet 2], który w zaawansowanym programie szkoleniowym wykorzystał element gamifikacji. GMC to gra na bazie symulacji komputerowej stworzonej dla biznesu, w której zespoły (3-5 osób) zarządzają firmami i konkurują z innymi na wirtualnym rynku. Drużyny pracowni- 
cze mogą tworzyć pracownicy różnych działów/specjalizacji, co dodatkowo sprzyja wymianie wiedzy i poszerza zakres zainteresowań uczestników. Symulacja prowadzona jest w formie współzawodnictwa. W każdej krajowej edycji wyłaniany jest zwycięzca, który następnie reprezentuje kraj na finałach światowych. Mamy więc tutaj element typowej rywalizacji między wszystkimi uczestnikami, grającymi na tych samych zasadach o osiągnięcie jednego celu. Rozgrywka nie jest toczona indywidualnie przez każdy zespół. Drużyny podzielone są na grupy, w ramach których rywalizują o osiągnięcie jak najwyższego wyniku inwestycyjnego. Decyzje jednej drużyny mają wpływ na konkurentów z grupy, przez co zachodzi pełna interakcja między uczestnikami. Przekłada się to na duże zaangażowanie emocjonalne, a ono z kolei potęguje przyswajaną wiedzę i motywuje graczy do pracy nad symulatorem i do poprawiania wyników swojej wirtualnej firmy.

Tabela 1. Przykłady realizowanych w Polsce projektów gamifikacji

\begin{tabular}{|l|c|c|c|c|}
\hline \multicolumn{1}{|c|}{ Projekty gamifikacji } & Obszar & $\begin{array}{c}\text { Grupa } \\
\text { docelowa }\end{array}$ & Poziom & $\begin{array}{c}\text { Rok } \\
\text { realizacji }\end{array}$ \\
\hline S4You & marketing & B2C & 1 & 2013 \\
\hline Sony Computer Entertainment & marketing & B2C & 1 & 2014 \\
\hline Odkrywaj i Wygrywaj & marketing & B2C & 2 & 2013 \\
\hline Brygada 7 Zbóż & marketing & B2C & 2 & 2014 \\
\hline HBO Play & marketing & B2C & 2 & 2014 \\
\hline Akademia Asów & miejsce pracy & $\begin{array}{c}\text { B2E } \\
\text { pracownicy działów } \\
\text { sprzedaży }\end{array}$ & 2 & 2015 \\
\hline Dobry Agent & B2E & 2 & 2016 \\
\hline HAYS & miejsce pracy & B2B & 3 & 2013 \\
\hline Inspiratorium Menrutacja & B2E & 3 & 2015 \\
\hline Autostrada Rozwoju & miejsce pracy & B2E & 3 & 2016 \\
\hline Drabina Rozwoju & miejsce pracy & B2E & 3 & 2016 \\
\hline GetBadges & miejsce pracy & B2E & 3 & 2017 \\
\hline Global Management Challenge & miejsce pracy & B2B & 4 & 2017 \\
\hline
\end{tabular}

Źródło: opracowanie własne.

Analiza przedstawionych przykładów pozwala wnioskować, że działania gamifikacyjne w firmach są skoncentrowane przede wszystkim na promowaniu marki i zarządzaniu zaangażowaniem pracowników. Promowanie marki w projektach gamifikacji jest jednak związane z działaniami, które wychodzą naprzeciw obowiązującym trendom w zakresie nowego stylu życia, zdrowego odżywiania czy zwiększonej aktywności fizycznej. W zarządzaniu zaangażowaniem pracowników obserwujemy przede wszystkim działania nakierowane na: aktywizowanie pracowników działów sprzedaży, promocję rozwoju pracowników, zaangażowanie pracowników na portalach społecznościowych w celu rekomendacji nowych miejsc pracy. 


\section{Zakończenie}

Młodzi ludzie z pokolenia milenijnego, którzy w coraz większym stopniu staną się częścią grupy konsumentów i pracowników, będą świadomie lub nie wybierać rozwiązania (nie tylko informatyczne) zawierające elementy znane z gier. Jak prognozował w roku 2012 J. Alexander, wprowadzenie elementów gier w różne aspekty naszego życia będzie odbywało się w sposób niezauważalny, co uczyni gamifikację dyskretnym, ale wpływowym narzędziem wpływu na nasze postępowanie w relacji do zasobów informatycznych i nie tylko [Anderson 2012].

Biorąc pod uwagę zmiany ogólnoświatowe, można stwierdzić, że gamifikacja w Polsce przebiegała podobnie jak w innych rozwiniętych krajach. Polskie firmy zareagowały szybko na pojawiający się trend, jednak po początkowym okresie fascynacji i podejmowania różnorodnych działań (2012-2013) nadszedł czas, w którym o gamifikacji wspominało się rzadko (2014-2015). Renesans działań gamifikacyjnych można zaobserwować od roku 2016, co można przypisać:

- rosnącej liczbie pracowników pokolenia milenium wchodzących na rynek edukacyjny i rynek pracy,

- zdobytym doświadczeniom, które umożliwiły uniknięcie błędów popełnionych we wcześniejszych projektach,

- większym wyborom platform i produktów gamifikacji,

- włączeniu gamifikacji w szerszy nurt działań metodycznych budowy aplikacji związany z User Experience (zob. np. [Scholtz, Raga, Baxter 2016]).

Można również przypuszczać, że w miejsce dużych projektów ramifikacji będzie następować dyfuzja rozwiązań do różnych obszarów organizacji i jako dojrzałe narzędzie motywowania pracowników gamifikacja będzie małymi krokami przenikać do środowiska codziennej pracy i odpoczynku. Elementy, które znamy z gier, będą się w ten w sposób przyczyniały do podniesienia jakości pracy i życia.

\section{Literatura}

Alexandrova A., Rapanotti L., Horrocks I., 2016, RE-PROVO: An evaluation of gamification in a law enforcement organization conference, ACM SIGCHI Annual Symposium on Computer-Human Interaction in Play (CHI PLAY 2016), vol. 1715, CEUR Workshop Proceedings - Proceedings of the Workshop on Fictional Game Elements.

Algoso D., 2014, Hype Cycle for Development Ideas: 2014 edition, http://algoso.org/2014/01/02/hypecycle-for-development-ideas-2014-edition/, dostęp: maj 2017.

Ali Darejeh, Siti Salwah Salim, 2016, Gamification solutions to enhance software user engagementA systematic review, Intl. Journal of Human-Computer Interaction, vol. 32, iss. 8 .

Anderson J., 2012, Gamification: Experts Expect 'Game Layers'to Expand In the Future, With Positive and Negative Results, PewResearchCenter: http://www.pewinternet.org/ /media/Files/Reports/ 2012/PIP_Future_of_Internet_2012_Gamification.pdf, dostęp: maj 2017.

Bajdor P., Dragolea L., 2011, The gamification as a tool to improve risk management in the enterprise, Annales Universitatis Apulensis Series Oeconomica, t. 2, no. 13, s. 38-50. 
Banuri S., 2016, Information and Communication Technologies, Gamification, and Public Sector Applications.,April2016, WorldDevelopmentReport,http://pubdocs.worldbank.org/en/445891461950116749/ WDR16-BP-ICT-Gamification-Public-Sector-Applications-BANURI.pdf.

Chou Y.-K., 2015, Actionable Gamification: Beyond Points, Badges, and Leaderboards, Octalysis Group, United States, revised edition.

Connolly T., Boyle E., MacArthur E., Hainey T., Boyle J., 2012, A systematic literature review of empirical evidence on computer games and serious games, Computers \& Education, 59(2), s. 661-686.

Diamantaki K., Rizopoulos C., Tsetsos V., Theona I., Charitos D., Kaimakamis N., 2013, Integrating game elements for increasing engagement and enhancing User Experience in a smart city context, Proceedings of the 9th International Conference on Intelligent Environments.

Gamification, 2014, http://www.trainingindustry.com/top-companies-listing/gamification/2014/2014top-20-gamification-companies-list.aspx, dostęp: maj 2017.

Gamification Failures, http://www.enterprise-gamifica-tion.com/mediawiki/index.php?title=Category:Gamification_Failures, dostęp maj 2017.

Gartner 2012, Gartner Says by 2014, 80 Percent of Current Gamified Applications Will Fail to Meet Business Objectives Primarily Due to Poor Design, http://www.gartner.com/newsroom/id/2251015, dostęp: maj 2017.

Hamari J., 2013, Transforming homo economicus into homo ludens: A field experiment on gamification in a utilitarian peer-to-peer trading service, Electronic Commerce Research and Applications, t. 12 , s. 236-245.

Heong Weng Mak, 2016, Insurance Companies Gamify Healthcare, http://www.gamification.co/2016/ 07/22/insurance-companies-gamify-healthcare/, dostęp: maj 2017.

Huizinga J., 1949, Homo Ludens - a Study of the Play-Element in Culture, Routledge \& Kegan Paul, London.

Huotari K., Hamari J., 2012, Defining Gamification: A Service Marketing Perspective, Proceedings of the 16th International Academic MindTrek Conference, Tampere, Finland.

Huotari K., Hamari J., 2016, A definition for gamification: Anchoring gamification in the service marketing literature, Electronic Markets, 26.

IEEE, 2014, http://www.ieee.org/about/news/2014/25_feb_2014.html, dostęp: maj 2017.

Kuo I., 2015, Nike+: Building Community and Competitive Advantage with Gamification, http://www. gamification.co/2015/08/03/nike-building-community-and-competitive-advantage-with-gamification/, dostęp: maj 2017.

Mechelen E., 2016, Implementing Gamification in Your Organization, Getting Buy-In from Your Boss, http://yukaichou.com/workplace-gamification/part1-buyinfromboss/.

Morschheuser B., Werder K., Hamari J., Abe J., 2017, How to Gamify? A Method for Designing Gamification, Proceedings of the 50th Annual Hawaii International Conference on System Sciences (HICSS), Hawaii, USA, January 4-7.

Negruşa A., Toader V., Sofică A., Tutunea M., Rus R., 2015, Exploring Gamification Techniques and Applications for Sustainable Tourism, Sustainability, no. 7, s. 11160-11189, www.mdpi.com/journal/sustainability.

Oprescu F., Jones C., Katsikitis M., 2014, I play at work - ten principles for transforming work processes through gamification, Front. Psychol., 5:14, https:/www.ncbi.nlm.nih.gov/pmc/articles/ PMC3906598/, dostęp: maj 2017.

Orange 2017, https://klubysportoweorange.pl/grywalizacja/, dostęp: maj 2017.

Paharia R., 2014, Lojalność 3.0, MT Biznes Ltd., Warszawa.

Scholtz B., Raga L., Baxter G., 2016, Design and evaluation of a "gamified" system for improving career knowledge in computing sciences, The African Journal of Information and Communication (AJIC), vol. 18, s. 7-32.

Strużyna J., Kania K., 2016, Strategiczne wyzwania gamifikacji, Zeszyty Naukowe Politechniki Śląskiej, Seria: Organizacja i Zarządzanie z. 88, nr kol. 1948, s. 289-298. 
Tkaczyk P., 2012, Grywalizacja bez mechanizmów, http://paweltkaczyk.com/p1/grywalizacja-bez-mechanizmow/, dostęp: maj 2017.

VerBruggen R., 2012, Games people play, Academic Questions, vol. 25, no. 4, s. 552-560.

Zuckerman O., Gal-Oz A., 2014, Deconstructing gamification: Evaluating the effectiveness of continuous measurement, virtual rewards, and social comparison for promoting physical activity, Journal Personal and Ubiquitous Computing, vol. 18, no. 7, s. 1705-1719.

\section{Internet}

[1] http://dziennikubezpieczeniowy.pl/2016/03/08/Dobry_Agent_Gothaer/artykul/103265, dostęp: maj 2017.

[2] http://gmcpoland.pl/idea-konkursu/.

[3] http://gra-miejska.blogspot.com/, dostęp: maj 2017.

[4] http://hrinnovator.pl/, dostęp: maj 2017.

[5] http://www.enterprise-gamification.com/mediawiki/index.php?title=Gamification_Examples, dostęp: maj 2017.

[6] http://www.gartner.com/newsroom/id/2575515, dostęp: maj 2017.

[7] http://www.gartner.com/newsroom/id/2819918, dostęp: maj 2017.

[8] http://www.gryfikacja.pl/index.php/2015/09/akademia-asow-czyli-gamifikacja-sil-sprzedazyred-bulla/, dostęp: maj 2017.

[9] http://www.media.pzu.pl/pr/295596/grupa-pzu-nagrodzona-za-program-rozwoju-menedzerow, dostęp: maj 2017.

[10] https://apps.facebook.com/odkrywajiwygrywaj/, dostęp: maj 2017.

[11] https://gamfi.pl/pl/klienci.html, dostęp: maj 2017.

[12] https://gamfi.pl/pl/textpage/grywalizacja-w-marketingu,55.html, dostęp: maj 2017.

[13] https://gamfi.pl/pl/textpage/przyklady-grywalizacji,51.html, dostęp: maj 2017.

[14] https://gamfi.pl/pl/textpage/rekrutacja,54.html, dostęp: maj 2017.

[15] https://gamification.financesonline.com, dostęp: maj 2017.

[16] https://gamification.financesonline.com/\#top10-products, dostęp: maj 2017.

[17] https://octalysisgroup.com/, dostęp: maj 2017. 